\title{
Nilai-Nilai Budaya Dalam Tam Tam
}

\author{
Ni Nyoman Karmini \\ Program Studi Pendidikan Bahasa dan Sastra Indonesia, Fakultas Pendidikan Bahasa dan Seni, \\ IKIP Saraswati \\ ninyomankarmini@yahoo.com
}

Tam Tam merupakan karya sastra Bali tradisional berbentuk geguritan. Geguritan memiliki sistem konvensi yang khas, yakni menggunakan pupuh. Setiap pupuh memiliki fungsi, dani padalingsa. Dalam tulisan ini, Geguritan Tam Tam dijadikan objek penelitian. Permasalahan yang diangkat dalam penelitian ini adalah mengenai nilai-nilai budaya dalam Tam Tam. Penelitian ini merupakan penelitian kualitatif sekaligus penelitian sastra yang dilaksanakan di perpustakaan. Data diperoleh dengan menggunakan metode dokumentasi dengan teknik catat. Data yang terkumpul dianalisis dengan metode hermeneutika. Hasil penelitiannya, ditemukan banyak sekali nilai budaya yang termuat dalam Tam Tam dan implisit di dalamnya tentang hukum karma phala.

Kata kunci: nilai budaya, sastra bali tradisonal, geguritan tam tam

\section{Cultural Values in Tam Tam}

Tam Tam is a traditional Balinese literary works shaped geguritan. Geguritan has a unique convention system, which uses pupuh. Every pupuh has a function, and padalingsa. In this paper, Geguritan Tam Tam made the object of research. Issues raised in this research is about cultural values in the Tam Tam. This research is a qualitative research as well as literature research carried out in the library. Data was obtained using the documentation method with note taking techniques. The collected data was analyzed by the hermeneutic method. The results of his research, found a lot of cultural values contained in the Tam Tam and implicit in it about the law of karma phala.

Keywords: cultural values, traditional balinese literature, geguritan tam tam

Proses Review : 7 - 25 Januari 2019, Dinyatakan Lolos: 29 Januari 2019 


\section{PENDAHULUAN}

Kesusastraan daerah merupakan bagian dari kebudayaan daerah. Kesusastraan daerah Bali merupakan bagian dari kebudayaan daerah Bali. Kesusastraan Bali, baik yang termasuk sastra Bali tradisional maupun sastra Bali modern mempunyai latar belakang yang berbeda dengan kesusastraan daerah lainnya yang ada di Indonesia. Karena itu, kesusastraan daerah Bali perlu dilestarikan serta dikembangkan. Semakin lestari dan semakin berkembang sastra daerah dapat mencerminkan perkembangan budaya bangsa.

Ciri khas kesusastraan Bali memberikan kebanggaan tersendiri bagi pemiliknya, yakni masyarakat Bali Hindu. Kebanggaan terhadap kesusastraan Bali disebabkan oleh sifat khasnya, yakni karya sastra yang menggunakan bahasa Bali. Banyak karya sastra Bali tradisional ditulis menggunakan huruf Bali, khususnya sastra tradisional yang ditulis dalam lontar. Hal itu merupakan saka guru kebudayaan Bali.

Bali sangat banyak memiliki dan menyimpan hasil karya sastra bermutu. Kesusastraan Bali dikelompokkan menjadi dua, yakni kesusastraan Bali Purwa (tradisional), dan kesusastraan Bali Anyar (modern). Sastra Bali Purwa dipilah menjadi dua bagian, yaitu sastra gantian (sastra lisan) dan sastra sesuratan (sastra tulis). Sastra gantian meliput: saa-saa, mantera-mantera, gegendingan, wewangsalan, cecimpedan, dan satua-satua. Sastra sesuratan mendapat pengaruh sastra Jawa Tengahan yakni yang berbentuk tembang macapat yang mulai berkembang di Bali pada abad XVII sampai sekarang. Sastra yang menggunakan tembang atau pupuh tersebut adalah kakawin, kidung, dan geguritan (Bagus dan Ginarsa, 1978:3-7; Karmini, 2008; 2016).

Kesusastraan Bali Purwa (tradisional), dijadikan objek kajian pada penelitian ini, khususnya sastra geguritan. Geguritan sebagai karya sastra, masih berkembang di masyarakat Bali dalam arti masih dihayati, dan pembacaannya disampaikan lewat tembang. Sejalan dengan tetap dihayatinya sastra geguritan, Putra (2010) menyatakan sastra modern yang menggunakan bahasa Bali juga mengalami perkembangan yang sangat menarik terbukti dengan terus terbitnya puisi, cerpen, dan novel berbahasa Bali, dan setiap tahun pengarang dan pembinanya mendapat hadiah Sastra Rancage.

Geguritan memiliki kode bahasa, kode sastra, dan kode budaya, yang sesuai dengan ciri khasnya, sebagai sastra daerah Bali. Geguritan berbentuk puisi karena terikat oleh aturan-aturan, yang disebut padalingsa. Geguritan dapat juga dikategorikan teks naratif karena memiliki rangkaian peristiwa yang membentuk sebuah kisah atau cerita. Geguritan sarat dengan pedoman-pedoman kehidupan, tentang etika, dan moral (Karmini 2016).

Geguritan sarat dengan pedoman-pedoman kehidupan. Pernyataan itu menimbulkan keinginan untuk menggali lebih dalam isi sebuah geguritan. Satu di antara banyaknya sastra geguritan yang ada adalah Geguritan Tam Tam. Geguritan Tam Tam, masa peneliti kecil dahulu, sering dituangkan dalam cerita Arja (sebuah tontonan tradisional Bali). Ceritanya sangat menarik sehingga peneliti tertarik untuk menelitinya. Setelah dipahami lebih mendalam ternyata di dalamnya memuat nilai-nilai budaya Hindu Bali. Nilai-nilai budaya adalah nilai- nilai yang disepakati dan tertanam dalam suatu masyarakat, lingkup organisasi, lingkungan masyarakat, yang mengakar pada suatu kebiasaan, kepercayaan (believe), simbol-simbol, dengan karakteristik tertentu yang dapat dibedakan satu dan lainnya sebagai acuan perilaku dan tanggapan atas sesuatu (Karmini, 2016:23). Nilai-nilai budaya Hindu Bali dimaksud sangat perlu diangkat kepermukaan dan disebarkan dalam bentuk tulisan dengan harapan diketahui dan dipahami serta diapresiasi oleh pembacanya. Harapan lebih jauh lagi adalah nilai-nilai budaya Hindu Bali dimaksud dapat dijadikan pondasi karakter diri sehingga seseorang menjadi lebih stabil dalam menghadapi era degradasi moral saat ini.

Berkaitan dengan uraian di atas muncul permasalahan, yakni nilai-nilai budaya apa saja terkandung dalam Geguritan Tam Tam? Sesuai permasalahan tersebut, maka tujuan penelitian ini adalah untuk mengetahui dan mendeskripsikan nilai-nilai budaya yang terkandung dalam Geguritan Tam Tam.

\section{METODE PENELITIAN}

Penelitian ini merupakan penelitian sastra dan sekaligus penelitian kualitatif. Penelitian kualitatif bertitik tolak dari paradigma fenomenologis. Objektivitas penelitian kualitatif dibangun atas rumusan tentang situasi tertentu sebagaimana yang dihayati oleh individu atau kelompok sosial tertentu, dan relevan dengan tujuan penelitian (Alsa, 2004:31). Ciri-ciri terpenting metode kualitatif, adalah (1) memberikan perhatian utama pada makna dan pesan, sesuai dengan hakikat objek, yaitu sebagai studi kultural; (2) lebih mengutamakan proses dibandingkan dengan hasil penelitian sehingga makna selalu berubah; (3) tidak ada jarak antara subjek peneliti dengan objek penelitian, subjek peneliti sebagai instrumen utama, sehingga terjadi interaksi langsung di antaranya; (4) desain dan kerangka penelitian bersifat sementara sebab penelitian bersifat terbuka; (5) penelitian bersifat alamiah, terjadi dalam konteks sosial budayanya masing-masing (Ratna, 2004:47-48). 
Berkait dengan jenis penelitian ini, maka data penelitian ini dikumpulkan dengan metode dokumentasi dengan teknik catat. Data yang terkumpul dianalisis dengan metode hermeneutika dan verstehen. Selanjutnya, hasil penelitian disajikan secara dekriptif dengan teknik induktif-deduktif.

\section{ANALISIS DAN INTEPRETASI DATA}

\section{Hasil Penelitian \\ 1. Sinopsis Geguritan Tam Tam}

Diceritakan ada dua roh di akhirat bernama Ginal dan Ginul, mantan murid Aji Saka dari pulau Jawa. Ginal dan Ginul berjanji menjelma ke dunia untuk menjadi orang terkenal, bijaksana dan berjodoh lewat adu kepandaian. Karena itu, kedua roh mencari pasangan suami istri, yang menjalankan ajaran-ajaran agama sebagai tempat untuk jalan kelahirannya.

Setelah mengembara ke Utara (ngutarayana), Ginul sampai di tanah Hindu dan bertemu suami-istri yang taat pada ajaran agama tetapi sangat miskin. Melalui pasangan ini, Ginul terlahir dengan nama Tamtam. Setelah mengembara di sembilan pulau, akhirnya Ginal menemukan keluarga raja Mesir, yaitu Prabu Basu Kesti, yang sangat bijaksana dan menjalankan prinsip "asta bharata” dalam memerintah. Di sinilah Ginal terlahir dengan nama Dewi

Adnya Swari.

Singkat cerita, Tamtam tumbuh menjadi pria yang sangat tampan dan berbakti kepada orang tua. Kedewasaan Tamtam berkat didikan orang tuanya yang menanamkan ajaran "dasa sila". Walaupun demikian, Tamtam tetap mencari seorang guru, sedangkan Dewi Adnya Swari dididik oleh Bhagawan Tresna Windu di istana. Setelah Dewi Adnya Swari tumbuh dewasa diadakanlah sayembara "adu kepandaian" untuk mencari pasangan hidup Sang Dewi, dengan syarat yang menang menjadi suami, sedangkan yang kalah bila seorang raja harus menyerahkan wilayah kekuasaannya.

Berita ini segera tersebar ke seluruh kerajaan Asia dan masyarakat kecil. Raja-raja Asia pun berdatangan ke kerajaan Mesir untuk mengikuti sayembara. Semua raja ini tidak berhasil mengalahkan Dewi Adnya Swari. Sayembara pun dibuka untuk umum termasuk rakyat jelata.

Mendengar hal itu, Tamtam yang sedang berguru di tanah Hindu, yakni di Pura Brata, pulang meminta doa restu kepada orang tuanya untuk mengikuti sayembara di Negara Mesir. Setibanya di Mesir, Tamtam memperkenalkan diri dan melontarkan pertanyaan tentang "isi kosong" (isin telas). Pertanyaan Tamtam tidak terjawab oleh Dewi Adnya Swari dan
Sang Putri meminta waktu selama tiga hari. Tamtam disuruh menginap di luar istana.

Pada malam kedua, Tamtam didatangi oleh Dewi Adnya Swari yang membawa minuman keras untuk membuat Tamtam mabuk, sehingga jawaban pertanyaan Tamtam dapat dikorek. Siasat Sang Putri mengena, tetapi Tamtam segera sadar. Terjadilah pergulatan antara sang Putri dengan Tamtam dan gelang Dewi Adnya Swari terlepas dan diambil oleh Tamtam.

Keesokan harinya di balai sidang istana, Dewi Adnya Swari menjawab pertanyaan Tamtam dengan benar. Sebelum Tamtam dinyatakan kalah, ia menjelaskan peristiwa semalam dengan menunjukkan bukti gelang Dewi Adnya Swari yang dibawanya. Mendengar penjelasan itu, raja marah dan menyatakan Dewi Adnya Swari kalah. Walaupun demikian, Dewi Adnya Swari diberi kesempatan untuk bertanya kepada Tamtam. Pertanyaan Dewi mengenai yama-niyama dijawab dengan benar oleh Tamtam, karena itu, Dewi Adnya Swari menyerah kalah.

Dengan kemenangan Tamtam, maka Tamtam dinikahkan dengan Dewi Adnya Swari dan dinobatkan menjadi raja Mesir dengan gelar Jayapurusa. Sejak Jayapurusa dinobatkan menjadi raja, maka kerajaan Mesir aman dan tentram. Selain itu, Jayapurusa diangkat menjadi seorang guru, maka seluruh raja Asia datang berguru kepada raja dan permaisuri.

\section{Struktur Intrinsik Geguritan Tam Tam}

Untuk memperoleh makna sebuah karya sastra, pembaca harus memahami secara keseluruhan karya sastra yang hendak dipahami. Dalam arti unsur-unsur dan hubungan antarunsur sebuah karya sastra harus dipahami. Untuk dapat memahami sebuah karya sastra, maka hubungan antara perwatakan, alur, dan latar, yang disebut dengan istilah fakta oleh Stanton (1965) (dalam Karmini, 2011:15) dapat mengarahkan pembaca ke arah permasalahan pokok (tema) dan nilai-nilai yang tercermin dalam karya sastra.

Dari sudut perwatakan atau penokohan, dan latar, peneliti mendapatkan gambaran bahwa watak tokoh yang ditonjolkan dalam Geguritan Tam Tam adalah tokoh yang sangat gemar belajar untuk memperoleh ilmu pengetahuan. Hal ini terjadi pada tokoh Tamtam dan tokoh Dewi Adnya Swari, yang dilukiskan oleh pengarang sejak awal cerita. Sang tokoh dilukiskan pada saat akan menjelma telah mempunyai perhitungan yang matang, yakni memilih pasangan suami-istri yang tepat sebagai perantara kelahirannya supaya nanti menjadi orang yang bijaksana dan menguasai dunia. Hal itu dilukiskan pada bait $6-10$. Berikut ini dikutip bait 7, 9 yang mendukung uraian di atas. 
Agung alit kawaspada, patemun anak merabi, manelebang kediatmika, dasa sila tatas sami, asta brata wus kauri, punika sane katuju, dane Ginul ngawatara, tanah Hindune kaungsi, molih ditu, anak teleb ring kotaman (Tam Tam, Sinom 1, bait 7).

Terjemahannya:

Tua muda diperhatikan, pertemuan suami-istri, yang menerapkan kebajikan, memahami dasa sila, asta brata telah dikuasai, itulah yang dituju, I Ginul ke utara, menuju tanah Hindu, di sanalah ditemui, orang yang menerapkan keutamaan.

I Ginal mangkin kocapan, bingung ngalih panumadi, memilihin tos utama, mangda agung ngodag gumi, pulo sanga kasusupin, tan ana masuk ring kayun, ring tanah Mesir punika, manggih ratu ngastawari, sami adung, ngastawa mangda maputra (Tam Tam, Sinom 1, bait 9).

\section{Terjemahannya:}

I Ginal sekarang dibicarakan, bingung mencari tempat untuk lahir kembali, sebab memilih orang-orang utama, supaya besar dan berkuasa, pulau sembilan diselusuri, tidak ada berkenan di hati, di tanah Mesir itu, menemui Ratu ngastawari (permaisuri raja sedang memuja, memohon), semua serasi, berharap supaya mempunyai anak.

Dari kutipan di atas sangat jelas bahwa keluarga yang mempunyai ilmu pengetahuan, menjaga keharmonisan serta selalu menerapkan kebaikan dapat melahirkan orang utama. Hal itu dipertegas lagi dengan petuah-petuah yang diberikan oleh tokoh ayah kepada Tamtam, yang termuat pada bait 13, 14, 15, 16 . Berikut ini hanya dikutip bait 14, 16.

Siksa dewa ngamong manah, anak sebet kadi tatit, pesun manah dadi karsa, tetiga punika cening, momo angkara ulurin, gelah anak gelah aku, ngacep-acep apang wirya, malih sumbung ngaku ririh, anak sadu, tan wenang asapunika (Tam Tam, Sinom 1, bait 14).

Terjemahannya:

Betul-betul pikiran itu harus dikendalikan, kecepatannya seperti kilat, keluarnya pikiran jadi keinginan, tiga itu nak, ketamakan dituruti, milik orang milik$\mathrm{ku}$, berharap-harap berkuasa, dan sombong mengaku pintar, orang baik dan bijaksana, tidak pantas seperti itu.

Patute ngebekin jagat, maweh maring daging gumi, asung lwir tembresan toya, olas asih lemah wengi, tiru dewa apti sang lwih, darana yoga lantar ipun, semadine mamutusang, aywa dewa pati gunjih, duh sang bagus, elingang dewa elingang (Tam Tam, Sinom 1, bait 16).
Terjemahannya:

Kebenaran memenuhi dunia, disebarkan pada seisi dunia, seperti rembesan air, tolong menolong dan saling kasih siang malam, teladani anakku berharaplah pada orang utama, darana yoga (ajaran pemusatan pikiran dalam yoga) dasarnya, yogalah memutuskannya, janganlah ragu-ragu, anakku, ingatlah selalu.

Kutipan di atas menunjukkan bahwa orang tua (ayah) Tamtam menyadari sepenuhnya arti "pendidikan", dan "hakikat kebenaran" yang diterapkan dalam kehidupan. Di sini juga terkandung nilai "pendidikan sikap" dari orang tua kepada anak. Dilanjutkan juga dengan nasihat agar Tamtam menuntut ilmu dan menerapkannya dengan berpegang pada dharma dan kebenaran. Kutipan berikut ini menyatakan hal tersebut.

Da joh paek ngadu liat, okane nulia nyaurin, singgih bapa wantah titiang, nyuksmayang tutur jati, matetaki saking mangkin, melaksana nene patut, lunga mangumbara desa, ngulati dharmane jati, saking tuhu, menelebang kadiatmikan (Tam Tam, Sinom 1, bait 17).

Bapannyane kenyir nanggal, lamun saking cening jati, manyungkemin kasukseman, diastuke nora mabalik, suka lila bapa cening, lamun pikardine putus, tiruneng dewa ring jagat, margi dewa apang becik, aja surud, darma putuse jejerang (Tam Tam, Sinom 1, bait 18).

Di lain pihak, tokoh Dewi Adnya Swari, yang terlahir di kerajaan Mesir dan memperoleh pendidikan dari Bhagawan Tresna Windu dilukiskan sebagai tokoh yang mampu menyampaikan pesan-pesan tentang cara menjalani hidup dan kehidupan dan mampu mengalahkan banyak raja (raja-raja Asia). Hal ini terlihat dalam dialog-dialog dalam sayembara adu kepandaian.

Dialog pertama dilakukan oleh raja Siliwangi dari Utara Desa kepada Dewi Adnya Swari tentang banyaknya dan makna "tri" dalam jagat raya ini dan dalam diri sendiri. Dialog ini dijawab dengan baik oleh Sang Dewi. Misalnya tri dalam "jagat raya" ini, dapat dicari di pasar, seperti matang, masak, dan mentah (lebeng, nasak, dan matah), isi bumi/jagat raya adalah mandeg, lahir, dan tumbuh (ngendeg, lekad, dan mentik). Semua itu disebut dengan tri kaya, yakni tri artinya tiga, kaya artinya kekayaan bumi/jagat raya. Tri nadi adalah tanah, langit dan apah yang menyebabkan tumbuh rasa senang, tetapi itu tidak langgeng sebab bisa mati bisa hidup, bisa hilang bisa datang. Tri dalam "diri sendiri" adalah trimala, yang meliputi membela kesalahan; membela yang disenangi, dan saling membalas rasa malu. Tri murti, yang meliputi perbuatan, perkataan, dan pikiran yang tidak 
baik (tindak, munyi, dan manah). Tri beda yaitu sifat yang tidak berpijak pada kebenaran, yang meliputi: memaki kebenaran, tidak taat ajaran agama, mencari sesuatu dengan tidak halal (darma sadune keceda, agamane kelempasin, ngulah pikolih prajani). Tri naya adalah perbuatan yang bersifat menipu, yang meliputi: berkata dusta, berpura-pura seperti orang bijaksana, ingin terkenal dengan tipu muslihat. Tri sandhi berbuat dengan mengorbankan orang lain demi kepentingan diri sendiri, yang meliputi: mengharap kematian orang lain dengan akal jahat, angkara murka, dan mementingkan diri sendiri. Tri guna, yaitu satwam diingkari, rajah dan tamah dituruti.

Dialog kedua terjadi antara Dewi Adnya Swari dengan Raja Sri Narendra Kanda Bumi dari Wayabiya. Sri Narendra Kanda Bumi hanya mengandalkan ketampanan dan kekuasaannya dan tidak berbekal sastra. Beliau mendapat pertanyaan dari Sang Dewi, yakni tentang wiswa dan Arda Candra. Sri Narendra Kanda Bumi tidak dapat menjawab dan mengaku kalah lalu pulang.

Dialog ketiga dengan Raja Burbumi dari Rum. Raja Burbumi menggunakan daya guna sandi. Sang Putri sangat mengetahui daya upaya Raja Burbumi. Karena itu, ia siaga menghadapi dengan tekniknya sendiri. Sang Dewi mengajukan pertanyaan tentang sukla, dan swaran lontar tan pesurat. Jawab Raja Burbumi rupa sukla tidak perlu diperlihatkan, sedangkan lontar polos jawabnya adalah orang yang siang maupun malam kerjanya hanya tidur bangun dan selalu diberitahu. Raja Rum lalu bertanya tentang kasukan jagat. Dijawab oleh Sang Dewi dengan benar dan Raja Rum kalah dan pergi seperti orang gila.

Raja Kagapati dari Pascima datang dengan segala guna-guna, jimat, uang kepeng arjuna, manik asem, dan lain-lain. Dewi Adnya Swari sangat pandai lalu diterapkanlah tri naya untuk menghadapi Raja Kagapati. Putri membawa tempat sirih atau pecanangan atau pabuan dan adu pandang. Lalu Dewi Adnya Swari berpura-pura meminta obat kepada Raja Kagapati sebab ia sakit sangat berat. Lalu Dewi rebah. Raja Kagapati sangat senang dan bernyanyi karena mabuk kemenangan. Dewi Adnya Swari lalu bertanya tentang kamimitan. Raja Kagapati tidak memperhatikan dan tidak menjawab pertanyaan itu dan ia tetap bernyanyi. Akhirnya, Kagapati ditangkap karena dianggap gila.

Raja Kasi juga ingin mengikuti sayembara walau kalah, ia ingin berguru untuk mendapatkan pengetahuan. Karena itu, Dewi Adnya Swari mengajari Raja Kasi sebelum mempunyai istri, samara-gama gugu supaya mempunyai keturunan yang utama yang disebut putra sesana. Sebelum memilih istri dipikirkan dengan sematang-matangnya. Istri utama dari bangsa apa pun yang penting masih muda (anom), memahami ajaran dan semua keluarganya menjalankan kebaikan, bukan dari keturunan orang gila, bukan orang sombong. Salah memilih istri adalah jika mengambil saudara tiri, sepupu, saudara kandung, janda saudara tua maupun saudara adik, sebab keturunan akan sakit-sakitan, janda tiga kali juga tidak baik sebab akan putus keturunan dan jiwa melayang, anak yang tidak diketahui ayahnya (anak babinjat) sebab bisa mati atau putus keturunan. Pilihlah istri yang juga mencintai serta laksanakan upacara perkawinan. Setelah istri mengandung disertai dengan perbuatan baik dan selalu berdoa. Setelah selesai, Raja Kasi pulang.

Setelah semua raja Asia kalah, maka sayembara boleh diikuti oleh rakyat, jika kalah akan dibunuh, jika menang dijadikan suami dan raja. Tamtam yang berada di Pura Brata mendengar berita itu. Lalu pulang bertemu dengan orang tuanya dan menyampaikan berita itu. Tamtam direstui oleh orang tuanya. Ia pun mengikuti sayembara dengan pertanyaan telas. Dewi Adnya Swari telah merasakan sesuatu sehingga suaranya seperti takut-takut. Dewi Adnya Swari tidak dapat menjawab sebab hatinya deg-degan dan tidak tahu jawabannya. Ia pun menunda jawaban selama tiga hari. Kemudian dilaksanakan tipu muslihat untuk mendapatkan jawaban dari Tamtam. Pada hari ketiga, jawaban disampaikan oleh Sang Dewi, tetapi sebelum Tamtam dikatakan kalah, ia menjelaskan kecurangan Sang Dewi dan menunjukkan bukti gelang milik Dewi Adnya Swari. Dewi pun dinyatakan kalah dan menikah dengan Tamtam. Tamtam menjadi raja dengan nama Jayapurusa dan sekaligus menjadi guru seluruh raja Asia. Tamtam dapat mengalahkan Dewi Adnya Swari karena ia terus-menerus menambah ilmunya dengan melakukan pengembaraan untuk memperoleh ilmu. Karena keuletannya itu, ia berhasil dan mampu mengangkat derajatnya.

Dari sudut alur, Geguritan Tam Tam menggunakan alur tradisional, yang juga disebut alur kronologis. Cerita dimulai dari situation sampai denoumen. Dalam alur tersebut, yang paling banyak dilukiskan adalah peristiwa sayembara adu kepintaran. Bahkan pengarang melukiskan sampai peristiwa perubahan nasib Tamtam. Alur cerita sangat renggang sebab pengarang memasukkan dialog-dialog yang panjang dalam satu peristiwa, karena pengarang ingin menonjolkan nilai-nilai kehidupan melalui tokoh cerita, dengan tujuan membekali budi pekerti para pembacanya. Dengan demikian, dapat dikatakan bahwa Geguritan Tam Tam bertemakan "pendidikan, ilmu pengetahuan dan budi pekerti sebagai cermin kualitas hidup".

Dengan ditetapkannya tema seperti itu, maka amanat yang hendak disampaikan Geguritan Tam Tam dapat 
disimak dari percakapan-percakapan para tokohnya, terutama tokoh Dewi Adnya Swari dan tokoh Tamtam. Amanat yang dapat disimak dari Geguritan Tam Tam adalah ajaran "dasa sila", yaitu sepuluh tuntunan dasar dalam hidup ini. Berikut dikutipkan jawaban Tamtam terhadap pertanyaan Dewi Adnya Swari tentang yama-niyama.

Yama ika solah Bhuda, mamutusang solah luwih, budi ngami sri-yasa, dasa sila wus kahuri, tan lingu ring daging gumi, diatmika wantah satuwut, pangungsine kenirwana, solahe suluhin sahi, katah ipun, adasa wantah punika (Tam Tam, Sinom 2, bait 49).

\section{Terjemahannya:}

Yama adalah sikap Budha, selalu melaksanakan perilaku baik, budi mendasari perilaku, dasa sila telah dihayati, tidak tertarik pada isi dunia, tuntunan kebenaran selalu diikuti, sebagai jalan menuju nirwana (penyatuan kepada Tuhan), perilaku selalu diintrospeksi, banyaknya, adalah sepuluh.

Bacakanne ne kaucap, mawiwika olas asih, ngalap kasor munyi melah, pageh mengastiti widhi, menerima nora elik, kasugihan tan kahitung, pageh kadi surya mentas, sampun dasa jangkep sami, katah ipun, bacakaning dasa sila (Tam Tam, Sinom 2, bait 50)

\section{Terjemahannya:}

Dasar yang dibicarakan, berdasarkan cinta kasih, mencapai kemenangan dengan berkata benar, sangat taat berdoa kepada Tuhan, memiliki sesuatu tidak terlalu bangga, kekayaan tidak berarti, kukuh seperti matahari berjalan dari Timur ke Barat, telah bulat sepuluh banyaknya, yang disebut dasa sila.

Jika dibahas lebih lanjut, dasa sila merupakan pengembangan dari trikaya parisudha. Dalam Upadeça dinyatakan bahwa trikaya berarti tiga dasar perilaku manusia. Parisudha berarti yang harus disucikan. Dengan demikian, trikaya parisudha berarti tiga dasar perilaku yang harus disucikan, yang meliputi: manacika (pikiran), wacika (perkataan), dan kayika (perbuatan). Dari trikaya parisudha timbul sepuluh pengendalian diri, yang rinciannya sebagai berikut. Tiga macam yang timbul dari pikiran, meliputi: (1) tidak menginginkan sesuatu yang tidak halal, (2) tidak berpikiran buruk terhadap makhluk lain, (3) tidak mengingkari hukum karma phala. Empat macam berdasarkan perkataan, yang meliputi: (1) tidak suka mencaci maki, (2) tidak berkata kasar kepada makhluk lain, (3) tidak memfitnah, (4) tidak ingkar pada janji atau ucapan. Tiga macam lagi berdasarkan perbuatan, yang meliputi: (1) tidak menyiksa atau membunuh makhluk lain, (2) tidak melakukan kecurangan terhadap harta benda, (3) ti- dak berjina (Parisada Hindu Dharma, 1967: 50-51).

Selain larangan berdasarkan trikaya parisudha, masih ada tuntunan susila yang rinciannya lebih banyak, seperti panca yama brata, panca niyama brata, dasa yama brata, dan dasa niyama brata. Di sini panca yama brata, dan panca niyama brata tidak dibahas lebih lanjut, dan yang dibahas hanya mengenai dasa yama dan niyama brata karena diperbincangkan dalam Geguritan Tam Tam.

Dalam Upadeça dipaparkan bahwa dasa yama brata, meliputi: (1) anresangsya atau arimbawa, yang berarti tidak mementingkan diri sendiri, (2) ksama, berarti suka memahafkan dan tahan uji dalam kehidupan, (3) satya, berarti setia pada ucapan, (4) ahimsa, berarti tidak menyiksa dan membunuh, (5) dama, berarti dapat menasihati diri sendiri, (6) arjawa, berarti jujur mempertahankan kebenaran, (7) priti, berarti cinta kasih terhadap makhluk lain, (8) prasada, berarti berpikir tanpa pamrih, (9) madurya, berarti ramah tamah, sopan santun, lemah lembut, (10) mardawa, berarti rendah hati. Dasa niyama brata, meliputi: (1) dana, berarti pemberian sedekah, (2) idjya, berarti memuja Hyang Widhi dan leluhur, (3) tapa, berarti menggembleng diri, (4) dyana, berarti pemusatan pikiran terhadap Hyang Widhi, (5) swadhyaya, berarti mempelajari dan memahami ajaran suci, (6) upasthanigraha, berarti mengendalikan hawa nafsu kelamin, (7) brata, berarti taat akan sumpah, (8) upawasa, berarti berpuasa, (9) mona, berarti membatasi perkataan, (10) snana, berarti melakukan pensucian diri dengan sembahyang (Parisada Hindu Dharma, 1967:51-52).

Selain amanat yang telah disebutkan di atas, sebenarnya Geguritan Tam Tam masih banyak memberikan amanat-amanat yang lebih sempit sekupnya dibanding amanat yang telah disampaikan di atas. Amanat-amanat dimaksud, antara lain: (1) tentang menciptakan keturunan yang baik, (2) tentang pendidikan, (3) tentang sifat satria, (4) tentang hakikat kebenaran dan hakikat tujuan hidup, (5) tentang hukum karma phala. Berikut ini dibahas lebih lanjut amanatamanat dimaksud.

(1) Amanat tentang menciptakan keturunan yang baik Amanat tentang keturunan yang baik telah dibicarakan pada bagian awal Geguritan Tam Tam. Telah diuraikan di depan bahwa Ginal dan Ginul mantan murid Aji Saka hendak lahir ke dunia. Mereka memilih pasangan suami-istri yang taat beragama dengan harapan supaya mereka terlahir menjadi orang yang pandai dan bijaksana serta menguasai dunia. Hal ini dibicarakan pada bait 1-10 pupuh Sinom 1. Berikut ini hanya dikutip bait ke-4 dan 5 sebagai contoh disertai dengan terjemahan bebas. 
Saking meled nyeritayang, panumadin anak becik, wiwit saking pulo Jawa, Gina Ginul maka sami, sisian ida peranda sakti, Aji Saka sane dumun, mengadakan anak melah, wirya budi tan sinipi, silar silur, manumadi dadi lanang (Tam Tam, Sinom 1, bait ke$4)$.

\section{Terjemahan:}

Ingin sekali menceritakan, kelahiran orang baik, berasal dari pulau Jawa, bernama Ginal Ginul, mantan murid Aji Saka, yang menghasilkan orang baik, sangat berbudi, bergantian mereka lahir menjadi laki-laki.

Cutet mangkin ceritayang, doning ceceh manumadi, parluntate mangkin kocap, petan dane makekalih, manglayang nyusup ring sepi, ngawang awang dane sampun, ditu reke masubaya, sanggupe pacang numitis, mangda kasub, wicaksana ngodag jagat (Tam Tam, Sinom 1, bait ke-5).

Terjemahan:

Inti ceritanya kini diceritakan, karena sering lahir ke dunia, akhirnya dikisahkan, pembicaraan keduanya, yang melayang-layang di awan, sambil berjanji, tentang kesanggupannya lahir kembali, supaya menjadi orang terkenal, bijaksana dan menguasai dunia.

Secara eksplisit, hal itu juga dikisahkan ketika Dewi Adnya Swari berbicara tentang keturunan yang baik kepada Raja Kasi. Raja Kasi sebagai peserta sayembara yang tujuan pokoknya memang hanya untuk mendapatkan ilmu pengetahuan walaupun kerajaannya menjadi taruhannya. Bait-bait yang berbicara tentang hal tersebut di atas adalah bait $1-5$ pupuh Sinom 2. Berikut hanya dikutip bait ke-1 dan ke-4 disertai terjemahan bebas

Saking anom jwa dabdabang, mejanji ring anak istri, mangastawayang semara, keto patute sang $\mathrm{ka}$ lih, sadurunge pacang merabi, pengacepe sampun patuh, siang dalu ngajap tawang, sentanane mangda luwih, yaning adung, wenten ciri kapaswecan (Tam Tam, pupuh Sinom 2, bait ke-1).

Terjemahan:

Dari muda telah dipikirkan dengan matang, berjanji dengan seorang perempuan, memuja asmara, begitu mereka seharusnya, sebelum menjadi suami-istri, harapannya harus sama, siang malam, keturunannya harus baik/sempurna, jika telah sesuai, pasti ada hasilnya.

Wewehin antuk laksana, bobotane pelapanin, peteng lemah mangiyasaang, lanang istri mangastiti, ngastitiang rarene pasti, pamijile pang rahayu, keto kecaping agama, tan patut ika piwalin, duh Sang Pra- bu, mangda maputra utama (Tam Tam, pupuh Sinom 2, bait ke-4).

Terjemahan:

Sertai dengan perbuatan, kandungan diperhatikan dengan baik, siang malam suami-istri memohon, supaya bayi lahir selamat, begitulah dalam ajaran agama, tidak perlu disangkal, Ratu Sang Prabu, supaya berputra utama.

Dari kutipan di atas, jelas sekali pengarang berpesan kepada pembaca mengenai cara-cara yang harus ditempuh untuk pembentukan keluarga yang baik. Di sini pun terkandung pendidikan keluarga.

(2) Amanat tentang Pendidikan

Pendidikan tidak hanya diberikan setelah anak lahir tetapi pendidikan dapat diberikan sejak anak dalam kandungan. Pendidikan dalam kandungan dapat dilakukan dengan mengikuti pesan yang disampaikan pengarang dalam "memperoleh keturunan yang baik", sedangkan pendidikan setelah anak lahir dapat disimak pada Geguritan Tam Tam, bait 13-18 pupuh Sinom 1. Berikut hanya dikutip bait 13 sebagai contoh disertai terjemahan bebas. Bait ini memberi isyarat kepada pembaca bahwa semasih muda "belajar" itu sangat penting. Dalam belajar jangan melupakan kebenaran (dharma).

Dabdabang dewa dabdabang, mungpung dewa kari alit, melajah ningkahang awak, darma patute gugonin, da mamokak iri hati, duleg kapin anak lacur, da bongkak kaping awak, ento metu saking bibih, ngawe musuh, saking dabdab makaruna (Tam Tam, Sinom 1, bait 13).

Terjemahan:

Berhati-hatilah anakku, mumpung masih muda, belajarlah bertingkah laku, berpedomanlah kepada kebenaran, jangan sombong jangan iri hati, jangan mencela orang miskin, jangan menyombongkan diri, itu ke luar dari ucapan, dan membuat musuh, berbicaralah dengan hati-hati.

Pada bagian akhir dari Geguirtan Tam Tam pengarang juga berpesan lewat tokohnya kepada pembaca agar semasih muda haruslah berusaha memperkaya diri dengan ilmu pengetahuan. Pesan ini disampaikan oleh tokoh Tamtam yang telah dijadikan raja bergelar Jayapurusha. Pendidikan tentang "kebenaran sejati" ini disampaikan lewat pupuh Pangkur bait $1-18$. Pendidikan tentang "catur marga" disampaikan lewat pupuh Sinom 3 mulai bait $1-21$. pendidikan tentang "isi kebenaran dan yang empat" disampaikan lewat pupuh Smarandana 2 mulai bait 1-25 serta lewat pupuh Ginada 2 bait $1-10$. Berikut ini hanya dikutip satu contoh, yakni bait 10 pupuh Ginada 2 
disertai terjemahan bebas.

Sang Prabu Jayapurusha, seken patekete mangkin, duh Dewa Raja Asia, sasukate sami kantun, mekarya dewa saratang, naya pasti, pelajahin apang tatas (Tam Tam, pupuh Ginada 2, bait 10).

Terjemahan:

Raja Jayapurusha, nasihatnya sangat penting, wahai raja Asia semuanya, semasih hidup, pentingkanlah bekerja, upayakan yang pasti, dan pelajari sampai benar paham.

(3) Amanat tentang sifat satria

Yang dimaksud dengan sifat satria di sini adalah berani mengakui kekurangan sendiri dan mengakui kelebihan orang lain serta tidak melakukan kecurangan untuk menyembunyikan kekurangan diri sendiri. Hal ini dilakukan oleh Raja Basu Kesti kepada putrinya sendiri, yakni Dewi Adnya Swari. Untuk menjawab pertanyaan Tamtam, Dewi Adnya Swari melakukan kecurangan, yakni dengan membuat Tamtam mabuk. Setelah mabuk dikoreklah jawaban pertanyaan Tamtam dari mulut Tamtam sendiri. Namun, Tamtam segera sadar, maka dicarilah bukti untuk membuktikan kecurangan Sang Dewi. Bukti dimaksud membawa Tamtam dinikahkan dengan Dewi Adnya Swari dan sekaligus menjadi Raja dengan gelar Jayapurusha. Sifat satria Raja Basukesti dilukiskan pada bait 45 pupuh Sinom 2. Pesan itu sebenarnya disampaikan kepada pembaca supaya dalam melakukan sesuatu tetap berpijak pada sifat satria. Berikut ini kutipannya disertai terjemahan bebas.

Prabu Mesir lintang duka, ring putrane RadenDdewi, dudu solah satria utama, manyingse ngalih pikolih, endatan jati ratu luwih, mengaran purusa dudu, solah nyasar ring laksana, bapa jani mamoyanin, jatin ipun, cening kasor ring payudan (Tam Tam, pupuh Sinom 2, bait 45).

Terjemahan:

Prabu Mesir sangat marah, kepada putrinya, itu bukan sifat satria utama, mencari hasil dengan menyiksa, itu bukan ratu yang baik, dan disebut tidak pemberani, karena perilaku berbeda dengan perbuatan, sekarang ayah yang menilai, sebenarnya kau kalah melawan Tamtam.

(4) Amanat tentang hakikat kebenaran dan hakikat tujuan hidup

Geguritan Tam Tam menyampaikan ajaran mengenai dasa sila yang dapat dijadikan landasan untuk mencapai kebenaran dalam hidup ini yang dapat pula sebagai bekal untuk mencapai kebahagiaan, baik di dunia ini maupun di akhirat. Kebenaran adalah penyangga dunia dan tidak pernah hilang walaupun seisi dunia ini musnah. Kebenaran adalah asal mula adanya dunia ini. Kebenaranlah yang paling utama di dunia ini. Hal ini dilukiskan dalam dialog Tamtam kepada raja-raja Asia, yang disampaikan lewat pupuh Pangkur. Berikut ini dikutip beberapa contohnya serta diberi terjemahan bebas.

Yatna bapa mamirengang, sareng sami miwah watek mangiring, patute nika satuwuk, sane langgeng nora obah, nika setata, ngamong wates pinih kukuh, ida mikayunin tan tandingan, galang manyusupin gumi (Tam Tam, pupuh Pangkur, bait 2).

Terjemahan:

Senang bapa mendengarkan, semuanya yang mengikuti, kebenaran itu selamanya, abadi dan tidak berubah, itu selalu, memegang batas terkuat, pemikir tanpa tanding, terang memenuhi dunia.

Ida sane menabdabang, menetepang upacara daging gumi, lan pauger sane bakuh, maka wenang nyaroning jagat, nika winih, ngadakang magenep bulu, dumilahnya tan tandingan, galang menyusupin gumi (Tam Tam, pupuh Pangkur, bait 3).

\section{Terjemahan:}

Kebenaranlah yang mengatur, menetapkan segala yang berlaku di dunia, dan hukum terkuat, juga penyuci dunia, itulah yang pokok dan penyebab segala macam, kehebatannya tak tertandingi, terang memenuhi jagat raya.

Jika dikaitkan dengan tujuan hidup sesuai ajaran agama Hindu, maka tujuan hidup ini adalah untuk mencapai kebahagiaan abadi atau moksa. Tujuan hidup dimaksud tercermin dalam keseluruhan $G e g u$ ritan Tam Tam. Tujuan hidup inilah yang dimaksud dengan "kualitas hidup lebih baik", yang telah disebutkan pada tema. Pupuh Smarandana yang dikutip berikut ini, mengamanatkan agar pembaca tidak hanya mementingkan materi dalam menjalani kehidupan ini. Juga diamanatkan bahwa materi dapat membuat manusia lupa terhadap hakikat tujuan utama manusia hidup. Berikut ini dikutip beberapa bait, yakni bait 4 - 7 pupuh Smarandana 2 disertai terjemahan bebas. Katah sane wus mabukti, jadmane ne kahuluran, nulia lali ring kotamane, bingung nora lingu apa, edan paling maring jinah, yadin sugih jinah liyu, dudu ika ngaran kasukan (Tam Tam, pupuh Smarandana 2, bait 4).

\section{Terjemahan:}

Banyak telah terbukti, orang yang hidup berlebihan (harta), lupa dengan keutamaan hidup, bingung tidak ingat apa-apa, tergila-gila pada uang, walaupun kaya dan uang banyak, bukanlah itu namanya kebahagiaan. 
Punika kasukan gumi, sinah ipun uning hilang, akweh jadma buduh keto, dening dewa kasujadman, sanget sugih mas perak, arepang anggen tatulung, pidanayang ring beraya (Tam Tam, pupuh Smarandana 2 , bait 5).

Terjemahan:

Itu kesenangan duniawi, yang bisa habis, banyak orang gila seperti itu, karenanya anakku sebagai manusia, jika kaya harta benda, utamakan untuk menolong, berikan kepada sesama.

Katah dewa wus mabukti, yan bandingang ring $i$ tiwas, dadi kuli slaku salon, ngajak kadang pianak somah, wantah jangkep asandangan, sadina tetep asuku, lega girang ya mecanda (Tam Tam, pupuh Smarandana 2, bait 6).

Terjemahan:

Banyak telah terbukti anakku, bila dibandingkan dengan si miskin, yang menjadi kuli dan mengajak semua keluarganya, hanya cukup sekali makan, sehari-hari tetap sangat sedikit, tetapi mereka selalu riang.

Bisa sahi ya magending, bandingang ring tumben tiwas, med ipun mati selsel, keto dewa yan rasayang, gede momo agung lara, awake kebatek kudu, swarga sarta dadi neraka (Tam Tam, pupuh Smarandana 2, bait 7).

\section{Terjemahan:}

Mereka dapat bernyanyi setiap hari, bandingkan dengan orang yang jatuh miskin, ia mati karena menyesal, begitulah anakku bila dirasakan, besar keserakahan besar pula kesengsaraan, terlalu menginginkan sorga tetapi menjadi neraka.

Kutipan berikut dapat pula mempertegas bahwa keterikatan terhadap materi dapat membuat manusia lupa terhadap tujuan hidup ini. Contoh ini dikutip dari pupuh Sinom 3, bait 12 dan 13 disertai terjemahan bebas.

Dini tongos paling kasar, pati selselan dumadi, dini tongos suka duka, tuwuh demene menglantarin, suka sekalane dini, boya iku suci tuhu, tan nyandang iku buwatang, eda mayus maminehin, aja punggung, ngekoh hati dewa melajah (Tam Tam, pupuh Sinom 3 , bait 12).

Terjemahan:

Di sini tempat yang jelek, tempat penyesalan kelahiran, di sini tempat suka dan duka, sebab kesenangan melatari, kesenangan duniawi di sini, bukan itu suci sebenarnya, dan tidak semestinya diutamakan, jangan malas berpikir, jangan kaku, dan jangan malas belajar.

Punika dados pelantang, ngawinang sukeh memargi, wates patute elingang, kurang demene talinin, mangda bebas jaga mulih, angungsi jagate luwung, siatin $i$ rajah tamah, patute dewa teliti, kadong caluh, nuwut rurung kasuniatan (Tam Tam, pupuh Sinom 3, bait 13).

Terjemahan:

Semua itu sebagai penyebab, yang menyebabkan sulit berjalan, batas kebenaran diingat, kesenangan dibatasi, supaya bebas pulang, menuju dunia yang indah dan abadi, lawanlah hawa nafsu dan rasa malas, kebenaran yang dituruti, supaya terbiasa, mengikuti jalan kemoksaan.

(5) Amanat tentang hukum karma phala Manusia hidup menjalani hasil karma-nya. Siapa yang berbuat dia pulalah yang menikmatinya. Apapun perbuatan seseorang itu pulalah yang dinikmatinya. Inilah yang disebut dengan "hukum karma phala". Amanat seperti ini termuat pada Geguritan Tam Tam, pupuh Smarandana 2 bait 22 yang dikutip berikut ini disertai terjemahan bebas.

Tur sambilang mengalapin, tetanduran duke kuna, manis pahit masem gelon, sang nandur patut ngrasayang, tong dadi ya pasingkwang, dening raga nandur dumun, onyang tong dadi sisayang.

Terjemahan:

Dan sambil memetik, tanaman yang ditanam dahulu, manis pahit asam dan yang tidak enak, yang menanam seharusnya menikmati, tidak bisa ditukarkan, sebab dahulu diri sendiri yang menanam, harus semuanya tidak bisa disisakan.

\section{Pembahasan}

Dari hasil penelitian di atas, diketahui bahwa Geguritan Tam Tam mempunyai alur kronologis karena rangkaian peristiwa bergerak dari situation bertahap sampai ke denoument, dan alurnya sangat renggang. Tema Geguritan Tam Tam adalah "pendidikan, ilmu pengetahuan dan budi pekerti sebagai cermin kualitas hidup".

Nilai-nilai budaya dalam Geguritan Tam Tam yang dapat digali: 1) roh utama dapat memilih dan menentukan pasangan suami-istri yang tepat untuk jalan kelahirannya, supaya nanti menjadi orang yang utama, bijaksana dan menguasai dunia (seperti Ginal dan Ginul dalam Geguritan Tam Tam); 2) Mempunyai prinsip kuat, gemar belajar untuk memperoleh ilmu pengetahuan, menyadari pentingnya arti pendidikan dan hakikat kebenaran; 3) Sebagai guru harus mampu 
menyampaikan pesan-pesan tentang cara menjalani hidup dan kehidupan (seperti Bhagawan Tresna Windu guru Dewi Adnya Swari); 4) Sebagai tokoh berpendidikan dan terdidik dengan baik, ilmu pengetahuan yang dimilikinya sangat luas, yang mengantarkannya memperoleh posisi yang baik dan terhormat; 5) Kejujuran penting dilaksanakan dalam kegiatan apapun termasuk dalam sayembara (seperti dalam cerita Tam Tam); 6) Macam-macam istilah tri ditemukan dalam Geguritan Tam Tam. Makna tri di jagat raya ini dapat dicari di pasar, seperti matang, $\mathrm{m}$ asak, dan mentah (lebeng, nasak, dan matah), isi bumi/jagat raya adalah mandeg, lahir, dan tumbuh (ngendeg, lekad, dan mentik). Semua itu disebut dengan tri kaya, yakni tri artinya tiga, kaya artinya kekayaan bumi/jagat raya. Tri nadi adalah tanah, langit dan apah yang menyebabkan tumbuh rasa senang, tetapi itu tidak langgeng sebab bisa mati bisa hidup, bisa hilang bisa anic. Tri dalam "diri sendiri" adalah trimala, yang meliputi membela kesalahan; membela yang disenangi, dan saling membalas rasa malu. Tri murti, yang meliputi perbuatan, perkataan, dan pikiran yang tidak baik (tindak, munyi, dan manah). Tri beda yaitu sifat yang tidak berpijak pada kebenaran, yang meliputi: memaki kebenaran, tidak taat ajaran agama, mencari sesuatu dengan tidak halal (darma sadune keceda, agamane kelempasin, ngulah pikolih prajani). Tri naya adalah perbuatan yang bersifat menipu, yang meliputi: berkata dusta, berpura-pura seperti orang bijaksana, ingin terkenal dengan tipu muslihat. Tri sandhi berbuat dengan mengorbankan orang lain demi kepentingan diri sendiri, yang meliputi: mengharap kematian orang lain dengan akal jahat, angkara murka, dan mementingkan diri sendiri. Tri guna, yaitu satwam diingkari, rajah dan tamah dituruti; 7) Tidak baik jika hanya mengandalkan ketampanan dan kekuasaan dan tidak baik jika tidak berbekal sastra; 8) Tidak baik menggunakan daya guna sandi; 9) Tidak baik jika terlalu mementingkan kesukan jagat; Tidak baik menggunakan guna-guna, jimat, uang kepeng arjuna, anic asem, dan lain-lain; 9) Prinsip memilih pasangan hidup: kari anom, memahami ajaran dan semua keluarganya menjalankan kebaikan, bukan dari keturunan orang gila, bukan orang sombong; 10) Untuk mendapatkan keturunan yang utama yang disebut putra sesana, Samara-gama gugu; Pilihlah istri yang juga mencintai; laksanakan upacara perkawinan; Setelah istri mengandung disertai dengan perbuatan baik dan selalu berdoa; 11) Jangan salah memilih istri, misalnya mengambil saudara tiri, sepupu, saudara kandung, janda saudara tua maupun saudara adik, sebab keturunan akan sakit-sakitan, janda tiga kali juga tidak baik sebab akan putus keturunan dan jiwa melayang, anak yang tidak diketahui ayahnya (anak babinjat) sebab bisa mati atau putus keturunan; 12) Makna sukla; 13) Swaran lontar tan pesurat; 14) Restu orang tua; 15) Makna tentang telas; 16) Asta bharata; 17) Dasa sila; 18) Yama-niyama; 19) Tentang kemimitan; 20) Sifat satria; 21) hakikat kebenaran dan hakikat tujuan hidup; 22) Tentang karmaphala.

\section{SIMPULAN}

Dari hasil dan pembahasan di atas, dapat disimpulkan bahwa Geguritan Tam Tam menggunakan alur kronologis dan alurnya sangat renggang, dengan tema "pendidikan, ilmu pengetahuan dan budi pekerti sebagai cermin kualitas hidup". Nilai-nilai budaya Hindu Bali yang ditemukan adalah roh utama, lahir dari pasangan utama, berpendidikan, taat ajaran, akan menjadi orang yang sangat dihargai; punya prinsip kuat, gemar belajar, menyadari pentingnya arti pendidikan dan hakikat kebenaran; Sebagai Guru harus melaksanakan tugas dan kewajiban dengan baik; pendidikan dapat mengantarkan pada posisi baik dan dihormati; kejujuran sangat penting; ditemukan bermacam-macam makna tri; jangan mengandalkan ketampanan dan kekuasaan saja dan tidak baik jika tidak berbekal sastra; tidak baik menggunakan daya guna sandi; tidak baik jika terlalu mementingkan kesukan jagat; tidak baik menggunakan guna-guna, jimat, uang kepeng arjuna, manik asem, dan lain-lain; ditemukan prinsip memilih pasangan hidup; untuk mendapatkan keturunan yang utama yang disebut putra sesana, Samara-gama gugu; pilihlah istri yang juga mencintai; laksanakan upacara perkawinan; Setelah istri mengandung disertai dengan perbuatan baik dan selalu berdoa; Ditemukan petuah jangan salah memilih istri, misalnya mengambil saudara tiri, sepupu, saudara kandung, janda saudara tua maupun saudara adik, sebab keturunan akan sakit-sakitan, janda tiga kali juga tidak baik sebab akan putus keturunan dan jiwa melayang, anak yang tidak diketahui ayahnya (anak babinjat) sebab bisa mati atau putus keturunan; ditemukan makna sukla; Swaran lontar tan pesurat; restu orang tua; makna tentang telas; ditemukan ajaran Asta bharata; Dasa sila; Yama-niyama; Tentang kemimitan; Sifat satria; hakikat kebenaran dan hakikat tujuan hidup; dan tentang karmaphala.

\section{DAFTAR RUJUKAN}

Alsa, Asmadi. 2004. Pendekatan Kualitatif dan Kuantitatif serta Kombnasinya dalam Penelitian Psikologi: Suatu uraian singkat dan contoh berbagai tipe penelitian. Yogyakarta:Pustaka Pelajar.

Bagus, I.G.N. dan I Ketut Ginarsa. 1978. Kembang Rampe Kesusastraan Bali Purwa. Buku I. Singaraja: Balai Penelitian Bahasa. 
Karmini, Ni Nyoman. (2008). "Sosok Perempuan dalam Teks Geguritan di Bali: Analisis Feminisme". Disertasi Program Doktor Linguistik. Universitas Udayana, Denpasar.

Karmini, Ni Nyoman. 2011. Teori Pengkajian Prosan Fiksi dan Drama. Pustaka Larasan bekerja sama dengan Saraswati Institut Press, Denpasar.

Karmini, Ni Nyoman. 2016. "Nilai-nilai Budaya dalam Geguritan Tam Tam". Penelitian yang ditaruh di Perpustkaan, Tabanan: IKIP Saraswati.

Parisada Hindu Dharma. 1967. Upadeça.

Putra, I Nyoman Darma. 2010. Tonggak Baru Sastra Bali Modern. Pustaka Larasan, Denpasar.

Ratna, I.N. Kutha. 2004. Teori, Metode, dan Teknik Penelitian Sastra: dari Strukturalisme hingga Postrukturalisme Perspektif Wacana Naratif. Yogyakarta: Pustaka Pelajar. 